\title{
alphauille
}

\section{Performing Gender in the Studio and Postmodern Musical}

\author{
Michael Charlton, Missouri Western State University
}

\begin{abstract}
This essay explores two distinct historical periods in the Hollywood musical through a Butlerian reading of gender as a performance. The two example films from the studio era, Howard Hawks' Gentlemen Prefer Blondes (1953) and the restored version of George Cukor's A Star is Born (1954), are contextualised not only within the studio system but through the constructed star personae of their leads-Marilyn Monroe and Judy Garland. Baz Luhrmann's Moulin Rouge! (2001) and Rob Marshall's Chicago (2002), the two example films from the twenty first century, are contextualised within a Jamesonian post-modern aesthetic and as examples of the non-studio, non-star filmic text as act of nostalgia. In contrasting these historical periods, the essay posits that the studio musical was, in fact, always already "post-modern" in its fragmentation of narrative in favour of the star performance, which constructs the gendered persona of the star. In addition, it is suggested that the sub-textual subversion of traditional female roles within the studio star performance is in many ways more effectively critical of gender conventions than the intentionally parodic aesthetics of Luhrmann and Marshall.
\end{abstract}

In this essay I draw on the work of Judith Butler to explore the formation of gender identity in two distinct historical periods in the Hollywood musical. I take two examples from the studio era, Gentlemen Prefer Blondes (Howard Hawks, 1953) and the restored version of A Star Is Born (George Cukor, 1954), to illustrate the gender politics associated with the role of the constructed star persona, in this case Marilyn Monroe and Judy Garland. Turning to two postmodern musicals, Moulin Rouge! (Baz Luhrmann, 2001) and Chicago (Rob Marshall, 2002), I consider the non-studio, non-star filmic text as act of nostalgia. In contrasting these examples from different historical periods, I posit that the studio musical was, in fact, always already "postmodern" in its fragmentation of narrative in favour of a star performance that constructs the gendered persona of the star. I argue, moreover, that the subtextual subversion of traditional female roles within the studio star performance is in many ways more effectively critical of gender conventions than the gender politics at work in the intentionally parodic aesthetics of Luhrmann and Marshall.

\section{Marilyn's Ghost: Stars, Generic Nostalgia and the Recovery of the Musical}

The musical's mainstream commercial and critical recovery in the twenty-first century was unexpected to say the least. ${ }^{1}$ One possible explanation for this recovery turns on the question of nostalgia in the postmodern musical, as embodied, for example, in the strange evocations of Monroe in the films under consideration here. Consider Jameson's description of the condition of 
postmodern art as the "waning of affect" and the consequent loss of authentic emotion in the decentred audience:

As for expression and feelings or emotions, the liberation, in contemporary society, from the older anomie of the centered subject may also mean, not merely a liberation from anxiety, but a liberation from every other kind of feeling as well, since there is no longer a self present to do the feeling. This is not to say that the cultural products of the postmodern era are utterly devoid of feeling, but rather that such feelings-which it may be better and more accurate to call "intensities"- are now free-floating and impersonal. (200)

Postmodern art is not lacking in emotion; rather, it evokes emotions that have no real object or purpose other than themselves and that do not connect to a single signifier. Jameson's postmodern "nostalgia film" abandons all notion of "historicity" and instead patently admits that the recreation of an era is simply "stylistic connotation, conveying 'pastness' by the glossy qualities of the image" (204). Understood in these terms, Luhrmann's gleeful inclusion of contemporary pop hits and Marshall's indifference to a realistic depiction of 1920s Chicago would be typical instances of postmodernism; the MTV-influenced style used by each director rejects even a stylistic evocation of the past in favour of imposing postmodern stylistic conventions that turn the past into the present.

All of this is undertaken against the backdrop of a perceived recovery of the musical genre from obsolescence. Chicago and Moulin Rouge! pay tribute to their older models in a particularly postmodern way: by dismantling them in order (presumably) to recover them. In his reading of both of these films, Dunne argues that they disarm a contemporary audience's dislike of the "artificial" musical with their non-realistic lapses into song and dance precisely by playing up how artificial they are; every song in Chicago is "presentational rather than representational" (that is, sung to an audience pictured within the film itself) in order to point out how unbelievable these moments are, thus, paradoxically, undermining an audience's urge to disbelieve (185). By making certain that every single moment feels synthetic, Luhrmann and Marshall find a postmodern glossiness capable of attracting that free-floating emotional response.

The evocation of Monroe has a similarly postmodern ring. It is important to note that the Monroe evoked by both directors is not really tied to any specific role. What matters, rather, is the complex system of signification with which her name has become equated. She is, at once, the archetypal Hollywood sex goddess and a meaningless cipher. There was, of course, no such person as "Marilyn Monroe"; she was a creation of the studio system and its publicity campaigns. As Harris notes, the studio consciously carried Monroe's "dumb blonde" persona over from her stereotypical roles in films to the "quotes and quips, known to the trade as Monroeisms" that appeared in interviews and magazine profiles (43). If she has become a camp icon since her death - the emblem of the naive sex kitten-she was constructed as such even during her career: "The image of the desirable playmate, which Monroe so exactly incarnated, is an image of female sexuality for men .... Part of what makes her desirable ... is that her image does not insist on a female sexuality for itself" (Dyer, "Monroe" 86). Monroe's simplicity as a 
signifier comes from this lack of response, this deliberate detachment not only from agency but from any responsibility for even itself.

Satine (Nicole Kidman) in Moulin Rouge! Plays Marilyn Monroe while singing, even during the intentionally ridiculous seduction scene inside the elephant, in which Monroe's breathy voice and sometimes exaggerated body language are evoked. Mechanisms of studio control forced Monroe to become nothing more than an image. In the postmodern era, the lack of studio control over an individual performer's career has had the interesting side effect of making the star persona less important or, conversely, of openly mocking it in order to market it (for example, Robert De Niro in Analyze This (Harold Ramis, 1999)). When Luhrmann and Marshall want to invoke a certain version of female sexuality, it is the image of the studio era to which they return. Kidman becomes nothing more than a screen on which to project a nostalgic/ironic ode to Monroe that simultaneously celebrates and mocks her exaggerated sexuality.

\section{All That Sex: The Musical Number as Gender Performance}

The postmodern musical persistently strives for distanciation: the audience is continually reminded that nothing here is real, whether it be through the medium of Roxie's hallucinations in Chicago (which apparently include all of the musical sequences in the film) or the well-known pop songs, intentionally garish production design and play-within-a-play-within-a-play structure of Moulin Rouge!. Arguably, this is motivated by a general cultural dislocation and an ironic, postmodern love for the hyperboles of the form. Yet the studio musical was no less aware of its own artificiality and conventionality. Britton contextualises the issue in broader terms:

Popular American movies presuppose an enormously sophisticated intimacy with the conventions of genre - an intense awareness of the logic of this dramatic world as distinct from that one - and Hollywood works by encouraging a kind of institutional formalism which freezes a film as an instance of the categories it employs. The spectacle is naturalized not because its conventions are invisible, but because they are referred to themselves. (200)

Indeed, spectacle is the governing convention of the musical and it is mostly the musical numbers that are its vehicle. The "logic of this dramatic world" is as non-"naturalised" as it could possibly be, but the audience's foreknowledge of how the musical world operates allows them to accept the narrative developments of the particular case: the musical number. For its part, the musical number often does little to advance the plot or even tell us more than we already know about the psychology of the characters (by the time the lovers reach their duet, the audience already knows they are in love). It is accepted and even celebrated as the spectacular performance of the character which stops the story dead in its tracks for a few minutes and, in the star musical, it is the very reason that audiences have come to see the film.

Though Laing argues that the "pleasurable illusion" of the musical number lies in the audience's feeling that the number is the "spontaneous, improvisatory composition" of the character-even when the songs are not original to the film, as in Moulin Rouge! - it could be 
argued that it is, conversely, the carefully choreographed, scripted and rehearsed performance that the audience embraces (8). Audiences come to see stars perform and tolerate the often tedious non-musical sequences because this is the price paid for spectacle. The musical film which focuses on the rise or fall of a female performer makes this audience desire all the more textual by turning the star into a star within the diegetic narrative as well as within the diegetic and non-diegetic music.

So, in many ways, the Hollywood studio musical was postmodern before the postmodern; it flaunted artificiality, style and the shattering of narrative structure in the place of spectacle. Stars are a central part of this, since star performers are not expected to play a character but rather themselves-Marilyn never disappears behind Lorelei Lee (the character she plays in Gentlemen Prefer Blondes); Lorelei Lee is Marilyn. (In this particular instance, Chicago and Moulin Rouge! are actually more classical in structure since, as non-star texts, their leading characters are presented as characters and not as cinematic icons or, rather, characters that are cinematic icons.) The emblem of the studio musical, the spectacular musical number, is accepted as a medium through which the star performer asserts his or her persona through song. In this way, the musical number is about constructing the identity of the star for the audience. Although this construction involves race, class, national identity and many other factors, within the conventional narrative of heterosexual romance the overwhelming identity markers are those of gender and sexuality. Monroe plays at being a sex kitten, an exaggerated femaleness which is almost drag. Garland in A Star Is Born, on the other hand, is constructed differently as a woman in her musical numbers, as I will argue later in the article, and gets to play more with the ambiguities of gender roles. But how might these constructions of gender and sexuality be understood in terms of contemporary feminist thought?

Gender Trouble, Judith Butler's now-canonical attack on essentialist and biological notions of gender, has surprisingly little to say about mass-cultural productions such as the Hollywood musical. Yet it is "production" and "performance" which are the key terms of her argument. According to Butler, gender identities are not natural, pre-supposed, or pre-existing but rather come to be through an imitation of imposed cultural norms:

And yet what determines the effect of realness is the ability to compel belief, to produce the naturalized effect. This effect is itself the result of an embodiment of norms, a reiteration of norms, an impersonation of a racial and class norm, a norm which is at once a figure, a figure of a body, which is no particular body, but a morphological ideal that remains the standard which regulates the performance, but which no performance fully approximates. ("Gender is Burning" 256)

Butler's notion of "realness" resembles Dyer's "construction of authenticity" in the star persona. Studio stars were created through an imitation of a pre-existing social stereotype; the persona is accepted as "real" because the star's body and its prescribed performances conform to such stereotypes. Thus, Monroe's body, for instance, becomes the "ideal" of the sex kitten, even though no one Monroe performance truly embodies this ideal. 
Monroe is particularly relevant to a discussion of Butler's ideas because her embodiment of this gendered ideal is intentionally over-the-top and verges on parody, unlike Garland's, as I will argue in more detail below. For Butler, a parody of gender roles may be seen in patriarchal culture when the arbitrary nature of these roles is flaunted:

Indeed, the parody is of the very notion of an original; just as the psychoanalytic notion of gender identification is constituted by a fantasy of a fantasy, the transfiguration of an Other who is always already a 'figure' in that double sense, so gender parody reveals that the original identity after which gender fashions itself is an imitation without an origin. To be more precise, it is a production which, in effect - that is, in its effect - postures as an imitation. This perpetual displacement constitutes a fluidity of identities that suggests an openness to resignification and recontextualisation; parodic proliferation deprives hegemonic culture and its critics of the claim to naturalized or essentialist gender identities. (Gender Trouble 175-6)

Parody points out that what it is imitating does not, in fact, exist. There is no pre-existing ideal to which society has attached its gender conventions. Rather, gender conventions have come about because of an imposition of this ideal on the actual. The performative nature of this imposition opens itself up to parody, to a "resignification" that highlights the falsity and polyvalence of such performances. Yet it is to the construction of gender through the central performative moment of the musical that this argument returns. By actively cutting the performative number off from its tenuous connection to the narrative as a whole it can be seen how such performative numbers create the star personae they claim to represent. These star personae are inextricably linked to the construction of gender ideals.

\section{Directors are a Girl's Best Friend: Cukor, Hawks and Feminist Film Criticism}

Gentlemen Prefer Blondes and A Star Is Born have peculiar reception histories. The first, a "dumb blonde" comedy constructed around a vapid sex symbol and directed by one of the most masculinist of studio directors, is generally praised by feminist critics. The second, a serious drama initiated by a fading yet well-respected female star and directed by a classical Hollywood women's director, is either ignored or denigrated by most feminist critics. Part of this has to do with the vagaries of auteurism, which has accepted Hawks into the auteurist canon but largely rejected Cukor (who directed My Fair Lady (1964), It Should Happen to You (1954), Pat and Mike (1952), Adam's Rib (1949), Gaslight (1944), Born Yesterday (1950), Dinner at Eight (1933), The Philadelphia Story (1940), Camille, (1936) and even part of Gone With the Wind (1939) but has been denigrated as a studio journeyman). Part of it also has to do with a somewhat clichéd critical theory about comedy and melodrama - that comedy allows for parody and satire while melodrama enforces conformity and assimilation. This dichotomy is problematic to say the least; to defend their theory, critics are forced to read films like Douglas Sirk's intentionally overblown soap operas as, essentially, comedies in drag. Yet these are the terms under which Gentlemen Prefer Blondes and A Star Is Born are largely discussed. Gentlemen Prefer Blondes has been one of the more curious recoveries of feminist film critics. Arbuthnot and Seneca celebrate the film as a rare example of a Hollywood musical in which women's pleasure is 
directed at each other instead of at men (for example, the infamous gymnasium scene featured in The Celluloid Closet (1995)). Mast argues, for example, that Hawks' camerawork creates an "absolute spiritual symmetry" between Jane Russell and Marilyn Monroe (113, 62). Brackett somewhat bizarrely celebrates Howard Hawks for liberating female characters by turning them into active beings; Wise concurs, claiming that the Hawksian woman is never "effeminate" (121, 118). Mulvey's essay on Gentlemen Prefer Blondes sees it as a studio film that actually denies the male gaze and "exaggerates the uncertainty associated with feminine masquerade" through the unstable "persona" of Lorelei Lee, thus pointing out the ludicrousness of the persona itself (226).

The prevailing message, in other words, is that we should celebrate the women in Hawks's films because they are not, in conventional Hollywood terms, women. The director either transforms them into honorary men or satirises their screen image so that they become simultaneously a sex symbol and a parody of a sex symbol. But there are dissenting voices too: Turim argues that the gender satire in Gentlemen Prefer Blondes is in many ways a diversion, a tease which distracts the audience from noting the film's deeper ideological problems with the "category" of "Woman" $(103,106)$. It is this thread that I wish to take up by contextualising Monroe's performance in "Diamonds Are a Girl's Best Friend" in two ways. First, I want to explore the allure of the Monroe myth for the two purportedly postmodern musicals under consideration here. With Butler's notion of gender performance in mind, what, I ask, is the relationship of imitation to original at work in the generic blonde Roxie (Renée Zellweger) and in Satine's rendition of "Diamonds Are a Girl's Best Friend"? Second, how is the gender performativity of Gentlemen Prefer Blondes recontextualised by what I will argue is the much more subversive - and ultimately "postmodern"-performance by Garland in A Star Is Born?

\section{"I'm Going to be a Celebrity_That Means Somebody Everyone Knows"}

Roxie Hart is supposed to be a mediocre singer and dancer and, even in her fantasy sequences, she is. Her big number, "Roxie", is framed by her conversation with Mama Morton, the prison matron played by singer Queen Latifah, about Roxie's plans after she is acquitted. This frame and the co-star are not incidental. For one, the audience's awareness of Queen Latifah as a highly successful musical performer casts Roxie (and, in turn, the musical novice Renée Zellweger) in a poor light. Later in the film, Mama Morton will colour and cut her hair into the same platinum blonde "Marilyn" style that Roxie sports. The image is comic because it reflects the flash-in-the-pan trendiness of Roxie's celebrity, but it also points to something more culturally disturbing, since "platinum blonde" signifies the white femininity that Mama Morton/Queen Latifah, who is of African American and Native American descent, obviously does not embody.

"Roxie" takes place in a world of blacks and whites. Zellweger's pale skin tone, diamond dress and blonde hair jump out from what is initially an empty black stage. She is first glimpsed as a reflection in the floor, the first of the mirror images that structure the song and point to the song's phantasmic nature but also to Roxie's humorously treated self-love. For all intents and purposes, Roxie sings "Roxie" for herself; she constructs her star image out of thin 
air as a form of self-empowerment. The governing irony, of course, is the tawdriness of her imagination: the tacky red neon of her name in lights, the banal handsomeness of her male chorus. She believes herself to be the greatest thing ever to happen to vaudeville but is, at best, a minor talent with stage patter directly stolen from bad vaudeville. While she pictures Mama Morton as grossly sexual, sticking fingers into men's drinks and bumping and grinding to the music, she pictures herself as "aloof" and ethereal. Unlike the elaborately designed club in Mama Morton's big number, "When You're Good to Mama", the blank expanse of the stage in "Roxie" presents itself as classy and eternal-just as she perceives platinum blonde to be. In the end, she floats out of sight like an angel ascending to heaven.

The joke, of course, is on Roxie, since her aloof and ethereal demeanour is the most transparently inappropriate showbiz gimmick for a tacky "chatterbox". Her imagination makes her into a puppet ("We Both Reached for the Gun"), a sideshow act in a three-ring circus ("Razzle-Dazzle"), and a successful female singer ("All That Jazz"). When she pictures other female performers, she sexualises them to the same degree that she sexualises herself in "Roxie". What Chicago suggests, depressingly, is that even the blonde's utopian thinking is tawdry. More than that, it denies Roxie even the performance of self that might have been afforded Monroe. All she is left with is the adoption of generic conventions associated with her character type (the platinum blonde) and the capacity to play that off against other archetypes: the eroticised African-American woman, the morally questionable brunette, etc. Far from Butler's vision of gender performance as "imitations without originals", Roxie's performance is condemned merely to play on stereotypes, recycling the only images she (or the film) has of a female performer. 


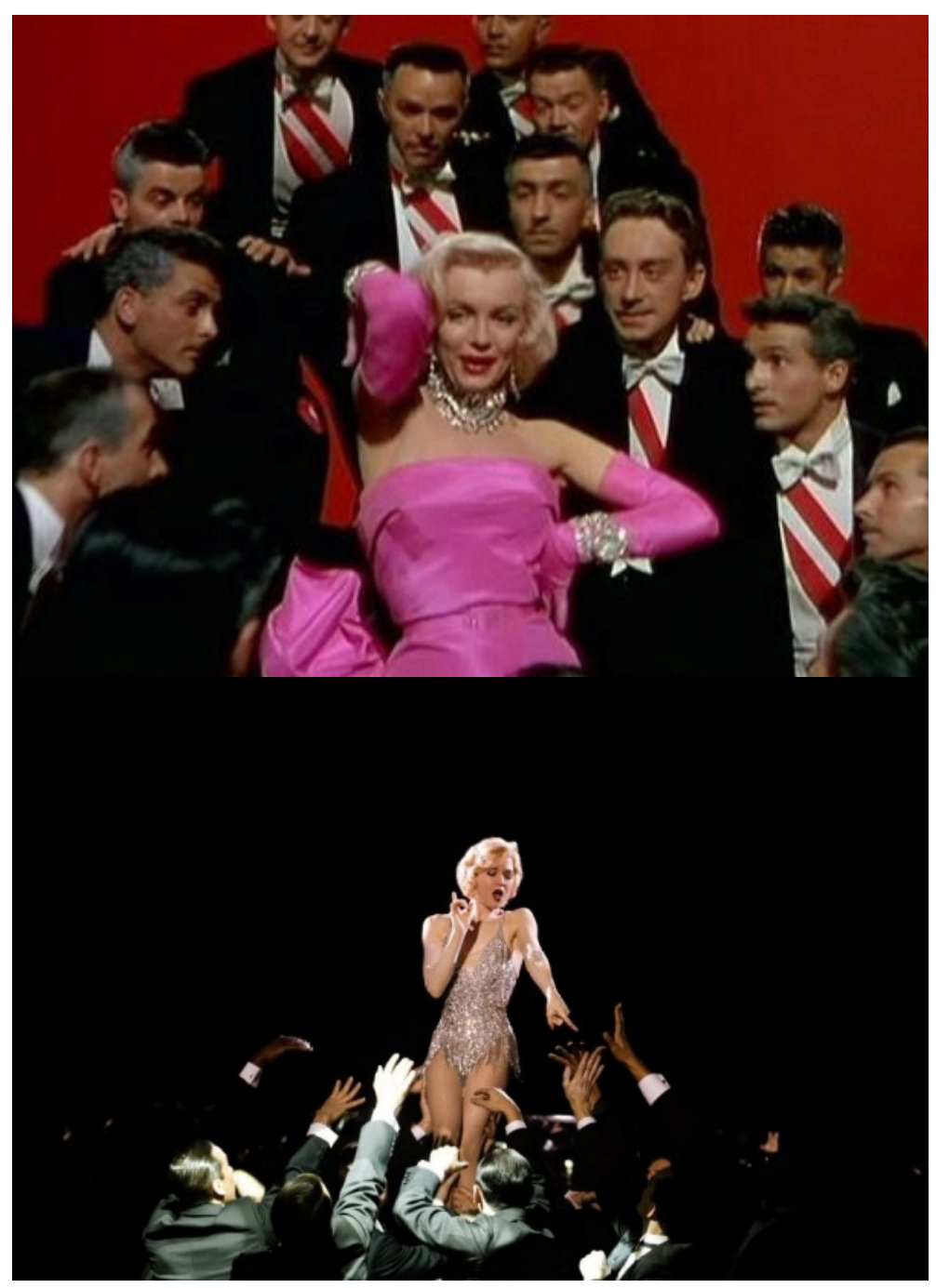

Marilyn Monroe in "Diamonds Are a Girl's Best Friend" (Gentlemen Prefer Blondes); Renée Zellweger in "Roxie" (Chicago)

Kidman's rendition of "Diamonds Are a Girl's Best Friend" is of course meant to evoke Monroe, but in a form refracted by Madonna's "Material Girl" video, itself a parodic take on Monroe. If Monroe's iconic image centres on passivity and a comic ignorance of her sexuality, Madonna foregrounds an ironic self-awareness in which her sexuality is both asserted and knowingly over-played. Interestingly, Satine's entrance scene actually embodies both personae. While the song summons Monroe, the more direct sexuality of Kidman's rendition and her more boisterous, eroticised physical movements during the song suggest Madonna (an allusion made concrete by an excerpt from "Material Girl"). Two apparent opposites in gender performanceoblivious passivity and active parody—are juxtaposed. ${ }^{2}$

In stark contrast to Roxie, who starts her big number as a reflection in the floor and ends it by ascending to the sky, Satine descends from the rafters as the goddess of the carnival run by Harold Zidler (Jim Broadbent) and finishes her number by falling to the floor. The audience is 
also reminded that, unlike Roxie, Satine is not her own narrator; the scene cuts to shots of Christian (Ewan McGregor) watching her initial arrival and of him writing the story on his typewriter. She is narrativised and commodified even before she appears; she is referred to as the "Sparkling Diamond" and so equated not only with the song but with wealth and status. More subtextually, she is associated with the same white femininity as Roxie's, not only via platinum blonde imagery (Monroe and "Material Girl" Madonna) but through the extreme paleness of Kidman's skin in the reflective light. This whiteness is highlighted by the contrast with the "Diamond Dogs", the darker-haired and darker-skinned women who serve as her back-up singers, and by Satine's eventual rescue by the black servant at the Moulin Rouge. Kidman's whiteness is also marked by the contrast between her diamond costume and the black tuxedos of the (white) men who offer her gifts and the occasional fondle. Again, it is the ethereal white woman who is commodified for male consumption. This time, though, the vehicle is not her own projected fantasies but the machinations of Zidler and the narration of the writer.

Moulin Rouge! seems like a more sophisticated play on genre than Chicago. Not only does its use of older songs allow it to instantly appropriate cultural meanings, but its more developed visual scheme and highly stylised acting open the way for a more deconstructive approach. Kidman as Satine is obviously playing up her role as sex kitten, pouting on cue at Zidler's offer of diamonds and whispering to him about her plans for the Duke (Richard Roxburgh). Satine is neither innocent nor oblivious but a somewhat willing player in her own objectification and commodification; her mistaking of Christian for the Duke is as much Zidler's fault as her own. The pantomimed sexual harassment between Satine and Zidler (actualising the lyric about the "hard-boiled employer") mocks the nature of this spectacle at the same time it takes its place within it. If she is being used, she also fully intends to use the Duke for her own ends. Unlike Roxie, Satine's hopes of being a successful "legitimate" performer are at least partially supported by the obvious enjoyment of her current audience. Her momentary conference with Zidler on what "type" will appeal to the Duke (invoking several different stereotypes of femininity) is the film's own commentary on its invocation of Monroe and other star personae.

A problem with Moulin Rouge! as a postmodern film is that, while it attempts to mock melodrama by pushing every moment past the limits of verisimilitude, it also attempts to recover melodrama by revealing a layer of genuine emotion which separates Satine and Christian from the artificiality of the Moulin Rouge and, by extension, the over-produced spectacle of the musical genre. This attempt at genuine emotion relies on the deployment of a feminine stereotype which is not mocked - what might be described as the hooker with a heart of gold. It is a stereotype of hidden sincerity not unlike the archetype behind Lorelei Lee, Roxie Hart and Vicki/Esther (Judy Garland) in A Star Is Born: the girl performer trying to find real love. While "Diamonds Are a Girl's Best Friend" parodies Hollywood femininity in its joking invocation of Monroe and Madonna and in the ironic self-awareness of Kidman as Satine, her sexualised role as "Sparkling Diamond" also attempts to set up a version of Satine that is not ironic. But the only narrative convention which allows for this is the same narrative convention that the film supposedly deconstructs. The postmodern star performance, which playfully references earlier icons, fails when the ironic detachment from those icons breaks down. Through the course of the film, Kidman arguably becomes Monroe (and Garbo and Dietrich, actresses whose performances 
of femininity are also evoked by Kidman in the film) merely repeating the gendered roles that they performed. The hyperbolic nature of the film paradoxically serves to underline the melodrama rather than subvert it.

\section{Norma Jean Baker and Frances Gumm Will Not Be Seen Tonight ${ }^{3}$}

So if the consciously postmodern musical falls short of deconstructing the gendered star persona precisely because it imitates the original it had seemed to subvert, what of the original itself? How does the star performance in the studio musical operate? A central part of the answer is that the star persona being invoked is not that of another star but that of the star performing: Monroe plays at being Monroe and Garland plays at being Garland. Rather than repeatedly refer back to another icon, they play their own iconic status for parody. They also get to play this parody within a film that is not stylised to mock its own generic conventions and predetermined to mock its own stars from the outset.

Despite its mythic status in film history, Monroe's rendition of "Diamonds Are a Girl's Best Friend" is pronouncedly and intentionally tacky. Sung for an aristocratic French audience (and for Monroe's nebbish suitor), it takes place on a bright red stage on which women in bizarre black fetish-wear form human candelabras. Monroe is surrounded by mannequin-like handsome (white) men in black tuxedos, her hair and skin gleaming against the garish background, just like Zellweger and Kidman. Allusions to burlesque abound: coquettish fans, evening gloves, a belt of diamonds tossed to the audience like discarded attire, not to mention the score, with its raunchy brass interjections. Like burlesque, too, the tone is parodic and teasing. At one point a smoky shaft of light illuminates Monroe as she sways her hips and vocally imitates a burlesque brass "doo-wa", echoed in falsetto voice by the male chorus. In spite of a moderately low-cut neckline, Monroe's pink dress is not deliberately provocative and revealing compared, for instance, to the dresses Monroe wears in other numbers of the film; and although she provocatively touches her long glove in a way that may suggest a strip-tease, she never removes it or anything else.

She races up and down stairs to escape from her packs of hungry suitors (carrying bright red cardboard hearts in their hands) and swats them away with her hand and a fan. Her first real line in the song is a repeated operatic trill on "No"- she is the ethereal platinum blonde goddess, not quite aware of how her demeanour drives men wild but willing to punish them for being attracted to her (one is reminded of Roxie's line about the "great big world-full of no" in "Roxie"). However, everything is not-so-subtly mocked by the burlesque tone of her performance; her broad arm gestures and breathy delivery parody the Monroe persona at the same time as it is being acted out on the stage. The audience is implicated in the men flocking around her, who are all willing to shoot themselves in the head rather than live without her. The grim nature of this suicidal pantomime mocks not only the goddess persona but the useless, passive men that surround Monroe's character in the film (one of whom watches her performance).

One of the curious things about the performance is that it is never quite clear to whom Monroe is singing; she does not exclusively address the song to the male chorus around her and 
rarely looks directly towards the audience until later in the number. In fact, she breaks the naturalistic frame by singing directly to the camera. When she does sing to an on-stage audience it is to a group of women dressed in pink ballet uniforms and with black stockings pulled over to obscure their faces. Implicitly, Monroe is invoking the persona of the gold-digger-giving other women advice on how to manipulate men-but the performance deconstructs this persona in the stressed anonymity of the other women. Apparently, Marilyn can give advice on to how to be Marilyn but there will only ever be one of her; all the other women are secondary.

Yet "Diamonds Are a Girl's Best Friend" repeatedly moves her into different stereotypes - aristocratic goddess, tease, gold digger, even the "dumb blonde". It is the multiplicity of stereotypes involved and the audience's attempt to equate all of these contradictory impulses (for example, the lyrics' sophisticated greed with Monroe's breezy lack of self-awareness) that challenges any simple gendered reading of the moment. Is she kidding or not? Although she grasps at the diamonds offered to her, she also throws them back in the men's faces. The entire number plays as a destabilising of the Monroe persona itself; the woman who is not quite aware of the effect she has on men and sells her sex appeal without becoming a prostitute is both celebrated and mocked.

Compared with the loud showstoppers "Roxie" and "Diamond's Are a Girl's Best Friend", Judy Garland's "The Man that Got Away" in George Cukor's A Star Is Born is a very different type of number. It is a blue torch song about lost love. Its placement within the larger narrative makes little sense, since Garland sings about losing a man in the scene where she first finds him. Even its performative purpose within the scene is strange. Ostensibly meant to convince Norman (James Mason) that Esther/Vicki is a genuine talent and not just the flashy performer from the opening show, the scene has her seduce a man by talking about how she was abandoned by one. While musicals usually feature lovers attracted by the sunny happiness of the other partner; here both characters are depressives. The typical musical heroine is plucky and determined but, in this number at least, she is suicidal and despondent. The choice is telling, since audiences in 1954 would be well aware of Garland's publicised suicide attempts and the mental problems that had sidetracked her career.

Curiously, Judy Garland had as much or more in common with the character of Norman Maine (and, by extension, with "The Man that Got Away") than with the character of Esther: Garland and Maine both saw meteoric highs and lows in their careers, both had substance abuse problems, both were notoriously unreliable on a set, etc. The fact that Garland and Sidney Luft, Garland's husband and the film's producer, chose A Star Is Born as her comeback vehicle suggests a high degree of awareness of how Garland was perceived by the public. This choice projected Garland's life story onto the male protagonist of the film as well as onto her own role. The audience is encouraged to find parallels, but is also faced with an unusual split in a Hollywood film, in which the male character is feminised and the female character is masculinised within the narrative through the star persona.

Though for years she cranked out formulaic films while under contract, Garland gained a larger degree of control over her own career with the huge success of her stage shows during the four-year absence from films that preceded A Star Is Born. In fact, it was her stage success which 
led to offers of a return to the screen: plans for A Star Is Born were proposed by close contacts and by Luft. Luft and Garland had considerable say in the selection of the director, the songwriters and much else. Obviously, the project of remaking the 1937 melodrama as a musical took account of Garland's talents, but the re-moulding of the earlier film went farther than that: the actress and screenwriter Moss Hart consciously worked on integrating stories and incidents from Garland's own life into the script (Haver 45). ${ }^{4}$ A Star Is Born represented for Garland a chance to create a persona for herself instead of being supplied with one. Interestingly, this happens not through the narrative but through the musical numbers. It is in performance that Garland subverts the role created for herself. Musicals, particularly star-driven musicals, highlight performance in a way that no other genre does: they are structured around the intermittent breaking of the narrative for a song and dance that both stresses and fragments femininity.

"The Man that Got Away" is structured and filmed as the antithesis of the normal star performance: it is intimate and introspective rather than public and explosive, it is moodily lit and relatively static rather than bright and dynamic, and it highlights not only the individual performer but the ensemble of which she is a part by starting with the entire group improvising and almost always showing Garland in spatial relation to the instrumentalists. In many ways, it is not filmed as a seduction scene; Garland seems unaware of Mason's presence until the end, singing at first to the trombone player, then to the pianist, and then mostly staring into space. Her outfit could hardly be more conservative: it is dark, covers almost every square inch of skin and, unlike Monroe's dress, does nothing to highlight Garland's cleavage.

Unlike the other three star performers, Garland's femininity and race are not particularly emphasised; if anything, the blues-club atmosphere and smoky lighting move the brunette Garland even farther away from the extreme whiteness of the platinum blondes and Kidman. She is presented as one of the "boys", just another performer sitting around and playing for her own pleasure. In the absence of a (visible) audience, she does not commodify herself in the way that Monroe, Kidman and Zellweger all do to varying degrees. This is a striking reversal of gender roles in the musical genre, which conventionally features performances in which men perform for their own pleasure or for the pleasure of other men, but which requires that women perform for an audience that normally includes men.

Even in her seduction scene Garland is not performing the expected generic role of the woman. She doesn't dance or sing for the men's pleasure and her only movements during the song consist of walking back and forth and a few hand gestures. As her star persona lacks the overt sexuality of Monroe's, with no consequent anticipation of a striptease routine, Garland gets to play around with the ambivalences of gender in performance. Though she is ostensibly supposed to be playing the naive ingénue, her world-weary vocal delivery and the strange darting eye gestures and physical tics suggest the "neurotic woman" persona that was starting to attach itself to her. By simultaneously suggesting a sequence of rigidly codified female roles_-girl singer, ingénue, male-identified woman, seductress, neurotic - and at the same time supporting and subverting them through reference to her off-screen persona, Garland becomes the woman that got away from the easy stereotypes of the star and studio system. 


\section{Always Already Postmodern}

The "star performance" of a female star, particularly one by an actress playing a performer within the narrative itself, represents a combustible mixture of assumptions about gender, power and identity. Through song and dance, icons such as Monroe and Garland were able to satirise and question public assumptions about themselves as well as stereotypes about women. The consciously postmodern musical, which attempts to mock the very form and convention of the genre it revisits, seems haunted by the classic musical, with implications for its own star performers. Far from the kind of Butlerian performative parody in which imitation lacks an original, gender performance in the postmodern musical seems to revive the essential truths that its models had questioned.

\section{Notes}

${ }^{1}$ On the recent revival of the film musical, see John Kenneth Muir, Singing a New Tune: The Rebirth of the Modern Film Musical, from Evita to De-Lovely and Beyond; Michael Dunne, American Film Musical Themes and Forms; and Kay Kessler, Destabilizing the Hollywood Musical: Music, Masculinity and Mayhem.

${ }^{2}$ Monroe is almost more of a presence during the initial seduction scene with her young lover, in which her breathy voice and physical movements are imitated for a stereotypical "dumb blonde" comedy scene of mistaken identity and seduction.

${ }^{3}$ Marilyn Monroe was born Norma Jeane Mortenson (but Mortenson was soon after changed to Baker) to Gladys Pearl Baker (née Monroe). Judy Garland was born Frances Ethel Gumm.

${ }^{4}$ Of course, much of the remake, including most of the basic narrative structure, is directly borrowed from the original. Haver also notes the influence of Cukor's What Price Hollywood?, a 1932 melodrama in which a rising actress is helped and then ruined by a suicidal, alcoholic director (43-4). Still, A Star Is Born represents an unusually self-determined and autobiographical project for a star under the studio system.

\section{Works Cited}

"All That Jazz". Chicago: Music from the Motion Picture. John Kander and Fred Ebb (comp.). Sony, 2003. CD.

Analyze This. Dir. Harold Ramis. Warner Bros., 2004. Film. 
Arbuthnot, Lucie, and Gail Seneca. "Pre-Text and Text in Gentlemen Prefer Blondes". Issues in Feminist Film Criticism. Ed. Patricia Erens. Bloomington: Indiana UP, 1990. 112-25. Print.

Bernardoni, James. George Cukor: A Critical Study and Filmography. Jefferson, N.C.: McFarland \& Company, 1985. Print.

Blake, Richard. “Certainly Chicago”. America 188.11 (2003): 23-4. Print.

Bowman, James. "Sneak Attack: Hollywood vs. History". American Spectator 34.6 (2001): 11618. Print.

Brackett, Leigh. "A Comment on 'The Hawksian Woman'”. Howard Hawks, American Artist. Ed. Jim Hillier and Peter Wollen. London: BFI Publishing, 1996. 120-2. Print.

Britton, Andrew. "Stars and Genre". Stardom: Industry of Desire. Ed. Christine Gledhill. New York: Routledge, 1991. 198-206. Print.

Butler, Judith. "Gender is Burning: Questions of Appropriation and Subversion”. Film Theory: Critical Concepts in Media and Cultural Studies. Vol. 3. Ed. Philip Simpson, Andrew Utterson, and K.J. Shepherdson. New York: Routledge, 2004. 249-66. Print.

---. Gender Trouble: Feminism and the Subversion of Identity. New York: Routledge, 1999. Print.

Carey, Gary. Cukor \& Co.: The Films of George Cukor and his Collaborators. New York: The Museum of Modern Art, 1971. Print.

The Celluloid Closet. Dir. Rob Epstein and Jeffrey Friedman. Sony, 1995. Film.

Chicago. Dir. Rob Marshall. Miramax Home Entertainment, 2004. DVD.

Cukor, George, dir. Adam's Rib. Loew's, 1949. Film.

---. Born Yesterday. Columbia Pictures, 1950. Film.

---. Camille. Metro-Goldwyn-Mayer Studios, 1936. Film.

---. Dinner at Eight. Metro-Goldwyn-Mayer Studios, 1933. Film.

---. Gaslight. Metro-Goldwyn-Mayer Studios, 1944. Film.

---. It Should Happen to You. Columbia Pictures. 1954. Film. 
---. My Fair Lady. Warner Bros. Pictures, 1964. Film.

---. Pat and Mike. Metro-Goldwyn-Mayer, 1950. Film.

---. The Philiadelphia Story. Metro-Goldwyn-Mayer, 1940. Film.

---. What Price Hollywood?. RKO Pathé Pictures, 1932.

"Diamonds Are a Girl's Best Friend". Gentlemen Prefer Blondes. Jule Styne (comp.). Twentieth Century Fox, 2001. DVD.

Drabelle, Dennis. "Macho Genius". Civilization 4.2 (1997): 56-62. Print.

Dunne, Michael. American Film Musical Themes and Forms. London: McFarland, 2004. Print.

Dyer, Richard. "Monroe and Sexuality". Women and Film. Ed. Janet Todd. New York: Holmes \& Meier, 1988. 69-96. Print.

---. "A Star is Born and the Construction of Authenticity". Stardom: Industry of Desire. Ed. Christine Gledhill. New York: Routledge, 1991. 132-40. Print.

Gentlemen Prefer Blondes. Dir. Howard Hawks. Twentieth Century Fox, 1953.. Film.

Gone With the Wind. Dir. Victor Fleming, George Cukor (uncredited), Sam Wood (uncredited). Selznick International Pictures, 1939. Film.

Green, Philip. Cracks in the Pedestal: Ideology and Gender in Hollywood. Amherst: University of Massachusetts Press, 1998. Print.

Harris, Thomas. "The Building of Popular Images: Grace Kelly and Marilyn Monroe". Stardom: Industry of Desire. Ed. Christine Gledhill. New York: Routledge, 1991. 40-4. Print.

Haskell, Molly. From Reverence to Rape: The Treatment of Women in the Movies. $2^{\text {nd }}$ ed. Chicago: University of Chicago Press, 1987. Print.

Haver, Ronald. A Star is Born: The Making of the 1954 Movie and Its 1983 Restoration. New York: Applause, 2002. Print.

Jameson, Fredric. "Postmodernism, or The Cultural Logic of Late Capitalism". The Jameson Reader. Ed. Michael Hardt and Kathi Weeks. Oxford: Blackwell, 2000. 188-232. Print. 
Johnston, Claire. "Women's Cinema as Counter-Cinema". Film Theory: Critical Concepts in Media and Cultural Studies. Vol. 3. Ed. Philip Simpson, Andrew Utterson, and K.J. Shepherdson. New York: Routledge, 2004. 183-192. Print.

Kaufman, Gerald. Meet Me in St. Louis. London: BFI Publishing, 1994. Print.

Kessler, Kay. Destabilizing the Hollywood Musical: Music, Masculinity and Mayhem. New York: Palgrave Macmillan, 2010. Print.

Kolker, Robert Phillip. "Woman as Genre". Women and Film. Ed. Janet Todd. New York: Holmes \& Meier, 1988. 130-49. Print.

Laing, Heather. "Emotion By Numbers: Music, Song, and the Musical". Musicals: Hollywood and Beyond. Ed. Bill Marshall and Robynn Stilwell. Exeter, England: Intellect, 2000. 513. Print.

Lambert, Gavin. On Cukor. New York: Putnam, 1972. Print.

MacKinnon, Kenneth. “I Keep Wishing I Were Somewhere Else': Space and Fantasies of Freedom in the Hollywood Musical". Musicals: Hollywood and Beyond. Ed. Bill Marshall and Robynn Stilwell. Exeter, England: Intellect, 2000. 40-6. Print.

"The Man that Got Away". A Star is Born (Expanded 1954 Film Soundtrack). Sony, 2004. CD.

Mast, Gerald. Howard Hawks, Storyteller. New York: Oxford University Press, 1982. Print.

“Material Girl”. Dir. Mary Lambert. Sire Records, 1985. DVD.

Moulin Rouge!. Dir. Baz Luhrmann. Fox Studios, 2001. Film.

Muir, John Kenneth. Singing a New Tune: The Rebirth of the Modern Film Musical, from Evita to De-Lovely and Beyond. New York, Applause Books, 2005. Print.

Mulvey, Laura. "Gentlemen Prefer Blondes: Anita Loos/Howard Hawks/Marilyn Monroe". Howard Hawks, American Artist. Ed. Jim Hillier and Peter Wollen. London: BFI Publishing, 1996. 214-29. Print.

"Razzle-Dazzle". Chicago: Music from the Motion Picture. John Kander and Fred Ebb (comp.). Sony, 2003. CD.

"Roxie". Chicago: Music from the Motion Picture. John Kander and Fred Ebb (comp.). Sony, 2003. CD. 
A Star is Born. Dir. George Cukor. Warner, 2001. DVD.

Turim, Maureen. "Gentlemen Consume Blondes". Issues in Feminist Film Criticism. Ed. Patricia Erens. Bloomington: Indiana University Press, 1990. 101-11. Print.

Tyler, Parker. "Mother Superior of the Faggots and Some Rival Queens". Film Theory: Critical Concepts in Media and Cultural Studies. Vol. 3. Ed. Philip Simpson, Andrew Utterson, and K.J. Shepherdson. New York: Routledge, 2004. 171-82. Print.

"We Both Reached for the Gun". Chicago: Music from the Motion Picture. John Kander and Fred Ebb (comp.). Sony, 2003. CD.

White, Dave. "Moulin Rumba". Advocate 860 (2002): 60-1. Print.

"When You're Good to Mama". Chicago: Music from the Motion Picture. John Kander and Fred Ebb (comp.). Sony, 2003. CD.

Wise, Naomi. "The Hawksian Woman". Howard Hawks, American Artist. Ed. Jim Hillier and Peter Wollen. London: BFI Publishing, 1996. 111-9. Print.

Wollen, Peter. Singin' in the Rain. London: BFI Publishing, 1992. Print.

\section{Suggested Citation}

Charlton, Michael. "Performing Gender in the Studio and Postmodern Musical". Alphaville: Journal of Film and Screen Media 3 (Summer 2012). Web. ISSN: 2009-4078.

Michael Charlton is an assistant professor of professional writing and rhetoric at Missouri Western State University. His MA thesis was completed under the direction of Dr Joanna Rapf at the University of Oklahoma and focused on the films of Orson Welles. His PhD work at the University of Oklahoma centred on visual rhetoric. Dr Charlton has forthcoming articles in Composition Studies and Programmatic Perspectives. 